\title{
Sacrococcygeal teratoma with intradural extension: case report
}

\author{
Shima Shahjouei, MD, MPH, ${ }^{1}$ Sara Hanaei, MD, ${ }^{1}$ Farideh Nejat, MD, MPH, ${ }^{1}$ \\ Maryam Monajemzadeh, MD, ${ }^{2}$ and Mostafa El Khashab, MD, $\mathrm{PhD}^{3}$
}

\begin{abstract}
Departments of ${ }^{1}$ Neurosurgery and ${ }^{2}$ Pathology, Children's Hospital Medical Center, Tehran University of Medical Science, Tehran, Iran; and ${ }^{3}$ Department of Neurosurgery, Hackensack University Medical Center, Hackensack, New Jersey
\end{abstract}

\begin{abstract}
Intradural sacrococcygeal teratoma (SCT) is a rare entity that has been reported in only a few cases previously. The authors present the case of a 2-week-old, otherwise healthy neonate with a mass in the buttock. The imaging findings and the high level of serum alpha-fetoprotein were highly suggestive of SCT. On operation the authors found intradural extension of the teratoma. The lesion was managed successfully without any remaining sequelae. The authors briefly review the currently proposed etiology regarding teratoma formation and the intradural extension of SCT.
\end{abstract}

http://thejns.org/doi/abs/10.3171/2014.10.PEDS1445

KEY WORDS sacrococcygeal teratoma; neonate; intradural; embryology; oncology

$\mathrm{T}$ Eeratomas are made up of 3 embryonic layers giving rise to a wide range of tissues. ${ }^{11}$ Sacrococcygeal teratoma (SCT) is the most common type of fetal teratoma, with great diversity in the degrees of maturity and invasiveness. ${ }^{7}$ In most patients with SCT, the tumor is successfully removed along with coccyx. Intradural invasion or extension of SCT is not common, and only a few cases have been reported previously (Table 1). Most patients with intradural teratoma have a pure teratoma without an associated sacrococcygeal lesion..$^{10,13-16}$ Permanent neurological deficits can be found in patients with intradural lipoma or intraspinal metastases of malignant SCTs. Sometimes early presentation of these kinds of tumors consists of deficits such as paraplegia and quadriplegia. ${ }^{10,13}$

We present the intradural extension of SCT in a neonate, briefly review the currently proposed etiology regarding teratoma formation, and discuss the possible embryological basis causing this kind of teratoma.

\section{Case Report}

History and Examination

A 2-week-old boy was referred to the neurosurgery department because of swelling in the buttock that had been present since birth. He was the second child of a healthy mother and was born following an uneventful pregnancy via vaginal delivery. There was no prenatal diagnosis of the lesion. Physical examination revealed a soft-tissue mass in the buttock with a maximum diameter of $7 \mathrm{~cm}$ that was covered by intact skin. All neurological examination results were normal. He had regular defecation and urination, with normal anal folds in addition to normal kidney and bladder ultrasound findings. Sacral MRI confirmed a cystic mass of the buttock extending through a widened sacral canal to the S-2 level with anterior displacement of rectum and bladder (Fig. 1). The mass was iso- to hypointense on T1-weighted images and hyperintense on T2weighted images (Fig. 2). Clinical diagnosis of SCT was considered. Alpha-fetoprotein and beta-human chorionic gonadotropin levels in serum were checked, and alphafetoprotein was abnormally high for the patient's age.

\section{Operation}

At surgery, the mass was found to be extended from the buttock toward the sacral canal. There was a widely bifid sacrum from S-5 to S-1 into which the stalk of the cystic mass was going intradurally; the mass was noted to be attached to a thick filum (Fig. 3). The capsule of tumor was in continuity with dura mater, through which the tumor entered the sacral canal and attached to filum. The roots inside the sacral canal were freely passing around the in-

ABBREVIATIONS NCC $=$ neural crest cell; SCT = sacrococcygeal teratoma.

SUBMITTED February 5, 2014. ACCEPTED October 7, 2014.

INCLUDE WHEN CITING Published online January 23, 2015; DOI: 10.3171/2014.10.PEDS1445.

DISCLOSURE The authors report no conflict of interest concerning the materials or methods used in this study or the findings specified in this paper. 
TABLE 1. Literature review of SCT cases associated with intradural extension

\begin{tabular}{|c|c|c|c|c|c|c|}
\hline $\begin{array}{l}\text { Authors } \\
\text { \& Year }\end{array}$ & $\begin{array}{l}\text { Patient } \\
\text { Age, Sex }\end{array}$ & Tumor Type & Region & Deficit & Time of Dx & Explanation \\
\hline $\begin{array}{l}\text { Koen et al., } \\
1998\end{array}$ & 12 days, $F$ & Mature & Sacrococcygeal & $\begin{array}{l}\text { No neuro def, neuro- } \\
\text { genic bladder, fecal } \\
\text { retention }\end{array}$ & $\begin{array}{l}\text { At birth (no } \\
\text { prenatal Dx) }\end{array}$ & Intradural \& extramedullary expansion \\
\hline $\begin{array}{l}\text { Dupin \& } \\
\quad \text { Sommer, } \\
2012\end{array}$ & 2 days, $M$ & $\begin{array}{l}\text { Immature } \\
\text { in 1st op, } \\
\text { mature in } \\
\text { 2nd op }\end{array}$ & Sacral & No neuro defs & $\begin{array}{l}33 \text { wks of } \\
\text { gestation }\end{array}$ & $\begin{array}{l}\text { Intrapelvic \& intraspinal expansion, } \\
\text { reop for recurrence or residue }\end{array}$ \\
\hline $\begin{array}{l}\text { Habibi et } \\
\quad \text { al., } 2007\end{array}$ & 2 days, $F$ & Mature & $\begin{array}{l}\text { Sacral, spinal, pel- } \\
\text { vic, \& abdominal } \\
\text { components }\end{array}$ & $\begin{array}{l}\text { Bilat flaccid paralysis } \\
\text { of LEs, low motor } \\
\text { function of hip }\end{array}$ & At birth & $\begin{array}{l}\text { Intraspinal intradural extension, } \\
\text { neurogenic bladder, high levels of } \\
\text { a-fetoprotein \& } \beta \text {-HCG }\end{array}$ \\
\hline $\begin{array}{l}\text { Hawryluk et } \\
\text { al., } 2012\end{array}$ & $N R, F$ & Mature & Sacral & No neuro defs & At birth & $\begin{array}{l}\text { Extension to spine \& sacral roots, } \\
\text { wound dehiscence \& discharge }\end{array}$ \\
\hline $\begin{array}{l}\text { Kunisaki et } \\
\text { al., } 2011\end{array}$ & $1 \mathrm{yr}, \mathrm{M}$ & Mature & Lumbosacral & No neuro defs & 1 st yr & $\begin{array}{l}\text { Colpocephaly, asymmetrical lumbosa- } \\
\text { cral MMC, SCM }\end{array}$ \\
\hline
\end{tabular}

$\mathrm{Dx}=$ diagnosis; $\mathrm{HCG}$ = human chorionic gonadotropin; $\mathrm{LE}=$ lower extremity; $\mathrm{MMC}=$ myelomeningocele; neuro def = neurological deficit; $\mathrm{NR}=$ not reported; $\mathrm{SCM}=$ split cord malformation.

tradural extension of the mass without any attachment to the tumor. Dura was opened and en bloc resection of lesion was done after cutting the attachment of the mass to the filum at the S-1 level. Complete closure of dura mater and skin was performed in separate layers. Pathological examination of the mass was diagnostic of mature teratoma (Fig. 4).

\section{Postoperative Course}

The postoperative period was unremarkable. No wound problem or CSF leakage occurred postoperatively. One year after surgery the patient's developmental status was within normal limits, with no neurological deficit. Serum alpha-fetoprotein was undetectable and the results of pelvic ultrasound studies were normal.
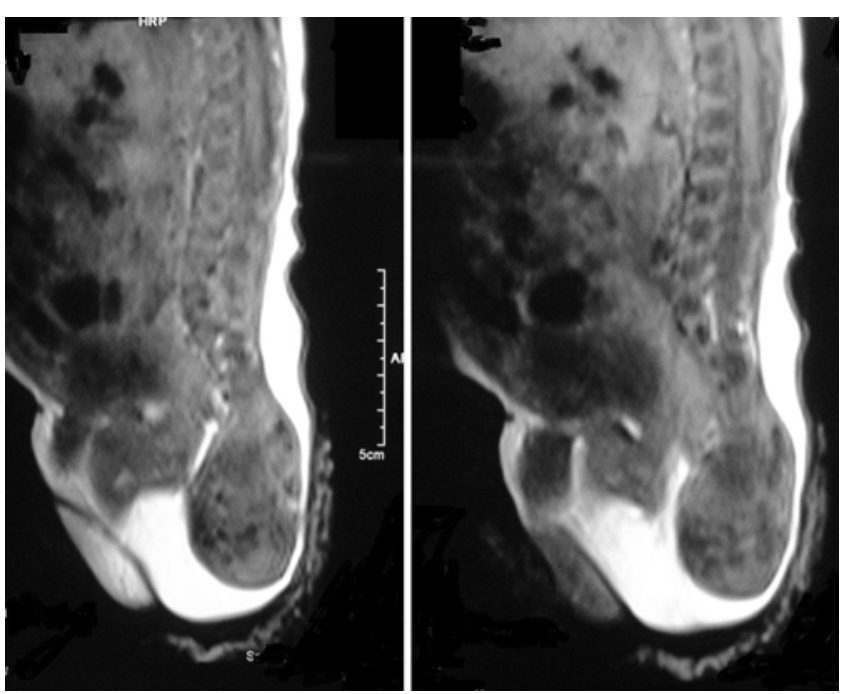

FIG. 1. Sagittal T1-weighted MRI studies of the lumbosacral area, confirming an iso- to hypointense mass of the buttock that seems to be extending to the sacral canal.

\section{Discussion}

Sacrococcygeal teratoma is the most common teratoma occurring in early life. ${ }^{7}$ Intradural teratoma is less common, but intradural extension or invasion of an SCT is much more infrequent. ${ }^{10,14}$ Tumors with intradural invasion are not associated with a higher probability of malignancy or recurrence..$^{10}$ Early presentation of this disease in some patients can be with severe neurological deficits like paraplegia. Therefore, early diagnosis and management of these lesions is important for preventing neurological sequelae. . $^{10,13}$

Although different theories have been proposed, the exact etiology of teratomas is unclear. The classic model of teratoma formation is based on the misplacement of primordial germ cells from the primitive yolk sac. ${ }^{5,6,11}$ Many
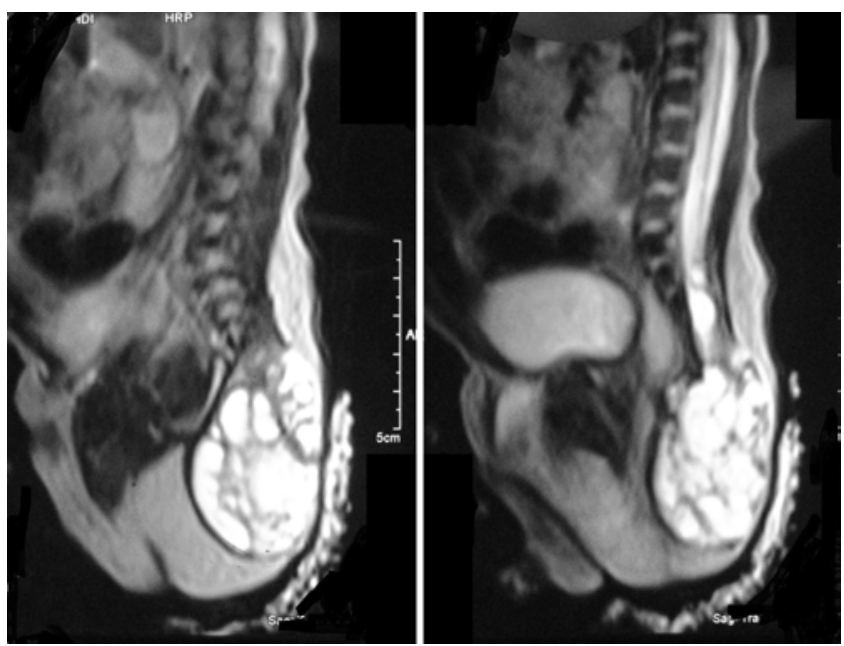

FIG. 2. Sagittal T2-weighted MRI studies showing a hyperintense mass of the buttock with probable intradural extension; note the cystic mass inside the sacral canal. 


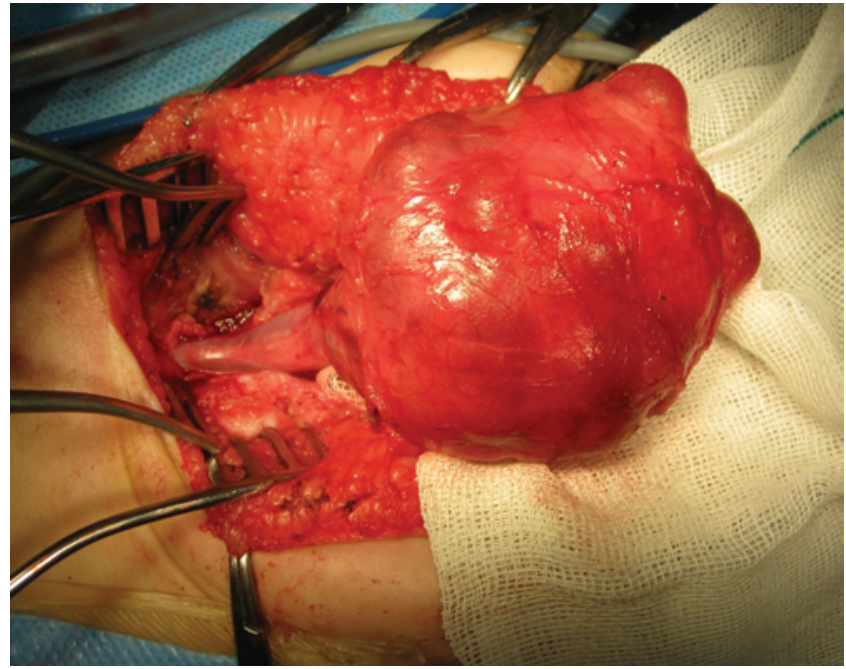

FIG. 3. Intraoperative photograph confirming the buttock mass that is in continuity with sacral dura mater and is extended to the sacral canal and attached to a thick filum. Figure is available in color online only.

cases of intradural spinal teratoma associated with dysraphic features such as split cord malformation, tethered cord, spina bifida, and myelomeningocele have been described. Despite the fact that not all spinal teratomas are associated with dysraphism, this association can lead to the dysembryogenic nature of teratoma formation. ${ }^{3,5}$

It has been suggested that mesenchymal progenitor cells in the caudal cell mass, which are remnants of the primitive streak and Hensen's node, have a pluripotent nature and are able to differentiate into the tissues derived from all 3 germ layers and cause teratoma formation. ${ }^{5,6}$

Supposing that mesenchymal cells are the cause does not explain the association between teratomas and dysraphisms. Instead, we suggest neural crest cells (NCCs) as the cause of these defects. Neural crest cells develop at the end of the 1st month of pregnancy. During and after folding of the neural tube, NCCs separate from the ectoderm at the boundary between neural and nonneural epithelia and form a mass dorsal to the neural tube, and then they start migration and differentiation to other tissues such as melanocytes, meninges, and sympathetic and dorsal ganglia. ${ }^{4,8}$

On the other hand, NCCs can easily differentiate to mesenchymal tissue, ${ }^{2,12}$ and detection of mesenchyme does not always mean caudal cell mass. Another important characteristic for teratoma formation is the ability to produce different tissues. It has been demonstrated that NCCs are pluripotent, show stem cell markers, and are able to self-renew., ${ }^{2,12}$ It is strongly supported that environmental factors play a crucial role in deciding the final fate of NCCs. ${ }^{2,9}$ As an example, the interplay of Wnt and BMP regulates the migratory and self-renewal capacity of NCCs. As these cells arrive at their targets, sensitivity and response to these factors decreases and the EGF/small Rho GTPase cascade became the main signaling pathway. ${ }^{1,2}$ Whereas Shh is a factor mediating migration through suppression of cell adhesion molecule integrin, RA inhibits NCC migration by stimulating the neural outgrowth, re-
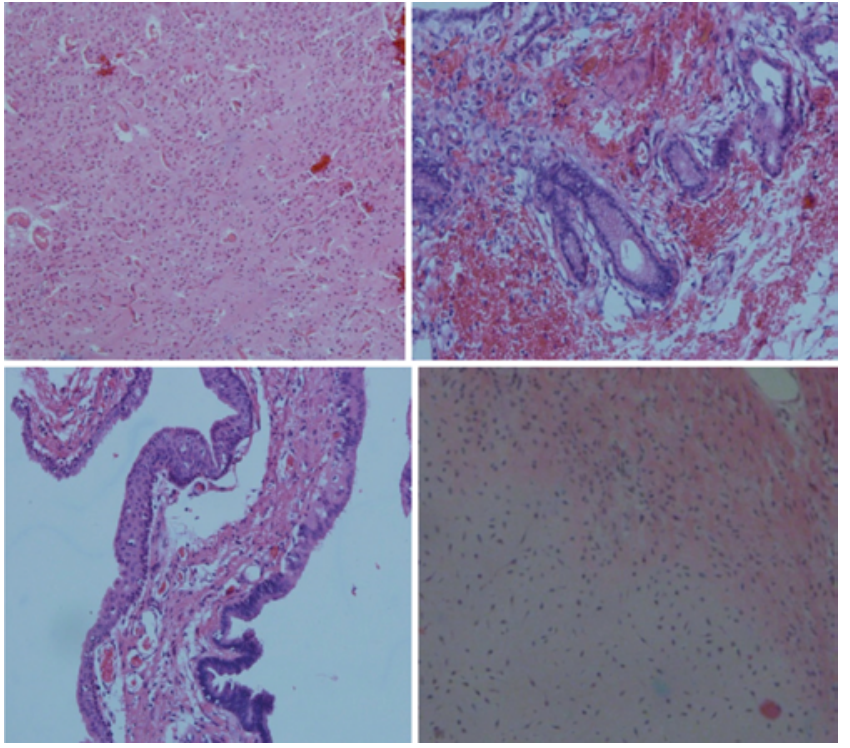

FIG. 4. Photomicrographs showing central neural tissue accompanied by glandular structure with cuboidal epithelium and an area of squamous epithelium associated with normal smooth muscle and vessels found inside the sacrococcygeal mass. $\mathrm{H} \& \mathrm{E}$, original magnification $\times 100$. Figure is available in color online only.

sulting in specification. ${ }^{4}$ Despite this, it has been shown that even after the completion of the migration, cells on the target location have multiple differentiation options. ${ }^{1}$ Therefore, any disturbance in the process of migration can end up with dislocation of these cells from their main target, causing a high potential for inducing teratoma.

Some authors have asserted that the midline position or dorsal origin of teratomas are a proof for germinal or mesenchymal models, ${ }^{5,6,11}$ but both of these properties are satisfied by assuming that NCCs are the responsible cells.

\section{References}

1. Dupin E, Coelho-Aguiar JM: Isolation and differentiation properties of neural crest stem cells. Cytometry A 83:38-47, 2013

2. Dupin E, Sommer L: Neural crest progenitors and stem cells: from early development to adulthood. Dev Biol 366:83-95, 2012

3. Habibi Z, Nejat F, Naeini PE, Mahjoub F: Teratoma inside a myelomeningocele. J Neurosurg 106 (6 Suppl):467-471, 2007

4. Hawryluk GW, Ruff CA, Fehlings MG: Development and maturation of the spinal cord: implications of molecular and genetic defects. Handb Clin Neurol 109:3-30, 2012

5. Jelin E, Jelin AC, Lee H: Sacrococcygeal teratoma with spinal canal invasion prenatally diagnosed. J Pediatr Surg 44:E9-E11, 2009

6. Kalani MY, Iyer S, Coons SW, Smith KA: Spinal intradural teratomas: developmental programs gone awry? Neurosurg Focus 33(4):E1, 2012

7. Koen JL, McLendon RE, George TM: Intradural spinal teratoma: evidence for a dysembryogenic origin. Report of four cases. J Neurosurg 89:844-851, 1998

8. Krispin S, Nitzan E, Kalcheim C: The dorsal neural tube: a dynamic setting for cell fate decisions. Dev Neurobiol 70:796-812, 2010 
9. Kulesa PM, Gammill LS: Neural crest migration: patterns, phases and signals. Dev Biol 344:566-568, 2010

10. Kunisaki SM, Maher CO, Powelson I, Gemmete JJ, Hirschl RB, Mychaliska GB: Benign sacrococcygeal teratoma with spinal canal invasion and paraplegia. J Pediatr Surg 46:e1e4, 2011

11. Lu YH, Wang HH, Lirng JF, Guo WY, Wong TT, Teng MM, et al: Unusual giant intraspinal teratoma in an infant. J Chin Med Assoc 76:411-414, 2013

12. Morikawa S, Mabuchi Y, Niibe K, Suzuki S, Nagoshi N, Sunabori T, et al: Development of mesenchymal stem cells partially originate from the neural crest. Biochem Biophys Res Commun 379:1114-1119, 2009

13. Nickols HH, Chambless LB, Carson RP, Coffin CM, Pearson MM, Abel TW: Intramedullary spinal immature teratoma: resolution of quadriplegia following resection in a 4-weekold infant. J Neurosurg Pediatr 6:586-591, 2010

14. Powell RW, Weber ED, Manci EA: Intradural extension of a sacrococcygeal teratoma. J Pediatr Surg 28:770-772, 1993

15. Ribeiro PR, Guys JM, Lena G: Sacrococcygeal teratoma with an intradural and extramedullary extension in a neonate: case report. Neurosurgery 44:398-400, 1999
16. Sözübir S, Rizalar R, Incesu L, Görk L, Aritürk E, Bernay F, et al: Lumbar teratoma with intraspinal extension. Pediatr Surg Int 11:421-422, 1996

\section{Author Contributions}

Conception and design: Nejat. Acquisition of data: Nejat, Shahjouei, Monajemzadeh. Analysis and interpretation of data: Shahjouei, Hanaei. Drafting the article: Shahjouei, Hanaei. Critically revising the article: Nejat, El Khashab. Reviewed submitted version of manuscript: Nejat, Hanaei, Monajemzadeh, El Khashab. Approved the final version of the manuscript on behalf of all authors: Nejat. Administrative/technical/material support: Nejat. Study supervision: Nejat.

\section{Correspondence}

Farideh Nejat, Children's Hospital Medical Center, No. 62, Dr. Gharib St., Keshavarz Blvd., Tehran 14155-7854, Iran. email: nejat@sina.tums.ac.ir. 